\title{
Ciddi Boş Zaman Faaliyeti Olarak Gönüllülük: AKUT Örneği
}

\author{
Volunteering as a Serious Leisure Activity: The case of AKUT
}

Faik ARDAHAN*

Öz: Bu çalışmanın amacı ciddi boş zaman faaliyeti olarak gönüllülüğü AKUT örneğinde ele alıp AKUT Operasyon Ekibi'nin gönüllü profilini belirlemektir. Araştırmanın veri uzayı ve örneklemi AKUT Kentsel Operasyon Ekibi’nde gönüllü olan toplam 408 kişiden oluşmaktadır. Bu çalışmada veri toplama aracı olarak demografik bilgilerin yanında; Ardahan (2015a) yılında geliştirilen AKUT'a Gönüllü Olma Ölçeğinin (AGOÖ) olduğu elektronik anket formu kullanılmıştır. Verilerin analizinde tanımlayıcı istatistiksel yöntemlerin yanında, normal dağılım koşulları yerine gelen karşılaştırmalar için Independent Samples Test ( $\mathrm{t}$ ), One Way ANOVA testi (F), normal dağılım koşullarının yerine gelmediği karşılaştırmalar için Mann-Whitney U (Z) testi gruplar arasındaki farkın belirlenmesinde Tukey-b testi kullanılmış ve sonuçlar 0.05 anlamlılık düzeyinde değerlendirilmiş̧tir. Sonuç olarak, AKUT’un Kentsel Operasyon Ekibi'nde gönüllü olan bireylerin önemli bir kısmı, doğa sporlarıyla aktif olarak ilgilenmekteler, spor dışı aktiviteleri olarak; arkadaşlarıyla ve ailesiyle birlikte olmakta, konserlere gitmekteler. Bunun yanında bireyleri rekreatif etkinliklere katılmaya motive eden birçok faktörün bireylerin AKUT’un Kentsel Operasyon Ekibinde gönüllü olması için önem arz etmediği, bu kurumda olma gerekçeleri sıradan, gündelik bir serbest zaman faaliyeti olan gönüllülü̈k yerine ciddi boş zaman faaliyeti olan gönüllülüktür.

Anahtar sözcükler: Ciddi Boş Zaman, Gönüllülük, Rekreasyon, AKUT

\begin{abstract}
The purpose of this study was to examine volunteering as serious leisure activity through the example of The Search and Rescue Association-AKUT, and to define the profile of the volunteers in the AKUT Operation Team. The group sampled consisted of 208 AKUT volunteers. In this study, an electronic questionnaire form which has demographics variables and the Motivational Factors Scale for being volunteer in AKUT developed by Ardahan (2015a) was employed. In the process of assessing the acquired data the descriptive statistic methods, Independent Samples Test ( $t$ ), One Way ANOVA test (F), Mann-Whitney U test (Z), were used, and the results have been assessed according to the significant level of 0.05 . As a result of this study; it was found that majority of the volunteers in the AKUT Operation Team were interested in outdoor sports and that they prefer family and friend companionship in their leisure time. Many factor which have influence individuals recreational preferences were not important for AKUT volunteers. Being a volunteer in the AKUT Operation Team and/or belonging to AKUT is a serious volunteer leisure activity for them, instead a casual leisure activity.
\end{abstract}

Keywords: Serious Leisure, Volunteering, Recreation, AKUT

Son zamanlarda hem gönüllülük hem de serbest zaman çalışan bilim adamlarının hepsi gönüllülüğü bir serbest zaman aktivitesi olarak ele almaktadırlar. En temel haliyle bakıldığında

\footnotetext{
* Doç. Dr., Akdeniz Üniversitesi, Beden Eğitimi ve Spor Yüksekokulu, Rekreasyon Bölümü, Antalya. ardahan@akdeniz.edu.tr

Bu Çalışma 5-7 Kasım 2015 tarihinde Eskişehir'de yapılan III. Rekreasyon Kongresi'nde sözel olarak sunulan bildirinin geliştirilmiş halidir.
} 
gönüllü olma, bir tatmin, ödüllendirme, tecrübe gibi kavramlarla ifade edilirken, tatmin ve ödüllendirme kavramları son zamanlarda daha çok eğlenceli ve zevk veren bir boyutta algılanmaya başlanmıştır. Bu haliyle gönüllülük kişisel boyutta bakıldığında bireylerin keyif aldıkları, eğlendikleri, bir tatmin, bir ödüllendirme ve tecrübe edinme aracına dönüşmüştür (Stebbins 1996a). $\mathrm{Bu}$ pencereden bakıldığında gönüllülük; "herhangi bir maddi kazanç beklentisi olmadan, herhangi biri tarafindan zorlanmadan ve yetkilendirilmeden, bireyin kendisi için değerli olan herhangi bir olaya, duruma ve sürece destek olmasi ve yardım etmesi" olarak tanımlanabilir (Van Til 1988). Buna ilave olarak gönüllülük Vikipedi'de "bireylerin herhangi bir karşıllk beklentisi içinde olmadan birey(ler)in kendiliğinden o işi yapmayı üstlenmesi, sürdürmesi" olarak tanımlanmışken, Sivil Toplum Geliştirme Merkezi (STGM 2006), "birey(ler)in maddi karşılık veya çıkar beklentisi olmadan yakın çevresi ve ailesindeki bireylerin dışındakilerin yaşam kalitesini arttırmak ve/veya kamu yararına olan bir işi/hedefi/uygulamayı gerçekleştirmek için bireysel olarak veya bu amaçla örgütlenmiş bir STK bünyesinde eylemde/aktivitelerde bulunması" olarak tanımlamıştır. Bu tanımların ortak noktaları gönüllülüğün; a) karşılık beklentisi olmadan yapılması, b) çoğunlukla içsel motivasyon veya bazı durumlarda dışsal motivasyonla içsel motivasyonun harekete geçirilmesiyle bireyin kendiliğinden bunu istemesi, c) bakmakla yükümlü olmadığı veya normalde sorumluluk alanına girmeyen konular/kişiler/durumlara yönelik olması, d) bireysel ve/veya başkalarıyla beraber formel veya enformel örgütlü olarak, e) bireyin bu işten manevi bir doyum elde etmesi ve müdahil olduğu durumlarda başkalarının da yaşam kalitesini arttırmasıdır. Tüm bu tanımların ortak noktasını bir araya getirip gönüllülük tekrardan tanımlanırsa (Ardahan 2015a) "birey(ler)in serbest zamanlarında, tamamen kendiliğinden ve doğru olduğuna inanarak, kişisel çıkar veya menfaat beklentisi olmadan, başkaları tarafindan zorlanmadan ve yetkilendirilmeden sonuçları itibariyle müdahale ettiği olayda pozitif katma değer yaratmak için çaba harcamalarıdır".

$\mathrm{Bu}$ tanımda verildiği haliyle bakıldığında gönüllülük iki boyutlu bir eylem olarak ortaya çıkar. Bunlardan ilki; "diyargamlık veya özgecilik olarak gönüllülük”, (alturizm-başkasının yararını kendi yararı kadar değerli görmek ve gözetmek veya diğer insanlara maddi veya manevi kişisel çıkar gözetmeksizin yararlı olmaya çalışma), ikincisi; "kişisel merak olarak gönüllülük”tür. Fakat daha sonraki uygulamalarda tecrübe edinmek için çalışma, sosyal ve kişisel ödüllendirmelerin varlı̆̆g, coşkuyla yapılan/yerine getirilen ciddi boş zaman faaliyeti olarak gönüllülük uygulamaları formları da bu gönüllülük uygulamalarına eklenmiştir (Stebbins 1996a).

Başlangıçta tüm serbest zaman aktivitelerinin gönüllü yapılan eylemler olduğu üzerinde durulurken daha sonra yapılan çalışmalarda gönüllülüğün bir serbest zaman aktivitesi olduğu üzerinde durulmaktadır. Henderson $(1981 ; 1984)$ gönüllülüğü; toplum yararına tamamlanması gereken ve daha çok harici, dışsal uyarıcılarla yönlendirilen hatta maddi olarak ödeme bile yapılabilen bir serbest zaman faaliyeti olarak görmüştür. Buna ilave olarak, Fischer ve Schaffer (1993) ile Thompson ve Bono (1993) yaptıkları çalışmalarda gönüllülüğün; a) o işin ustası olarak bilinme, b) aynı misyona sahip kurum/organizasyonların bir parçası olma, c) sevilen, profesyonel olarak gelişme ihtimalinin olduğu, kişisel yeteneklerin kullanıldığı bir işi yapmaktan tatmin duyma, d) kendini gerçekleştirme, kendini geliştirme/zenginleştirme, e) sosyal ilişkiler kurgulama f) bir ekibin parçası olma ve ekip olarak bir şeyi başarma, g) kişisel imaj elde etme gibi ödüllerin olduğunu ve önemli bir serbest zaman aktivitesi olduğunu belirtmişlerdir.

Literatüre bakıldığında spor, sağlık, yaşlı bakımı, erozyonla mücadele, itfaiye gibi birçok boyutta gönüllülük ve bireyi gönüllü olmaya motive eden faktörleri ele alan birçok çalışma yapılmıştır. Bu çalışmalardan bazıları şunlardır;

- Knoke ve Prensky (1984) çalışmasında diğer organizasyonlar için tanımlanan orga- 
nizasyon teorilerini gönüllü organizasyonlar için de sorgulamıştır.

- Thompson ve Bono (1993) çalışmasında gönüllü itfaiyecileri ele almıştır.

- Wymer ve arkadaşları (1996) çalışmalarında gönüllülüğün sosyal ve kişisel boyutlardaki belirleyicilerini ele alan bir çalışma yapmışlardır.

- Stebbins (1996b) çalışmasında ciddi boş zaman faaliyeti olarak gönüllülügüü sorgulamış ve kavramsal sınırlarını çizmiştir.

- Clary ve arkadaşları (1998) çalışmalarında “Gönüllü Fonksiyonu Ölçeği” geçerlilik güvenirlilik çalışması yapmışlardır.

- Farrell ve arkadaşları (1998) çalışmalarında elit spor organizasyonlarında gönüllülüğü sorgulamıșlardır.

- Clary ve Snyder (1999) çalışmalarında gönüllülüğün motivasyon süreçlerini çalışmişlardır.

- Farmer ve Fedor (2001) çalışmalarında sağlık sektöründeki gönüllüleri diğer sektör gönüllüleriyle karşılaştırmışlardır.

- Allison ve arkadaşları (2002) çalışmalarında Gönüllü Fonksiyonu Ölçeğini geliştirilen hali ve açık uçlu sorular sorularak elde ettikleri cevaplarla sonuçları karşılaştırmışlardır.

- Twynam ve arkadaşları (2002) çalışmalarında özel spor oyunlarında gönüllü olan bireyleri gönüllülüğe motive eden faktörler açısından sorgulamışlardır.

- Terrell ve arkadaşları (2004) çalışmalarında organ bağışçılarının gönüllülük gerekçelerini ele almışlardır.

- Gravelle ve Larocque (2005) çalışmalarında Fransa Oyunlarında gönüllü olan bireylerin gönüllülük gerekçelerini sorgulamıșlardır.

- Mowen ve Sujan (2005) çalışmalarında motivasyonel araçlar ve kişilik özellikleri açısından gönüllülüğü sorgulamışlardır.

• Brown (2005) çalışmasında turizm sektöründeki gönüllülüğü ele almıştır.

- Giannoulakis ve arkadaşları (2008) çalışmalarında Olimpik Oyunlarda Gönüllü Motivasyonu Ölçeği ile geçerlilik-güvenirlilik çalışması yapmışlardır.

- Bang ve Ross (2009) gönüllü tatmini ve motivasyonunu çalışmıştır.

- Finkelstien (2009) çalışmasında dişsal ve içsel boyutlarıyla motivasyon araçlarını sorgulamıştır.

- Gallant (2010) ciddi boş zaman faaliyeti olarak gönüllülük üzerine bir tez hazırlamıştır.

• Kim ve arkadaşları (2010) Gençlik ve Sporda Gönüllü Fonksiyonu Ölçeği üzerinde çalışmışlardır

- Yarnal ve Dowler (2002) çalışmalarında gönüllü itfaiyecileri incelemişlerdir.

- Mirsafian ve Mohamadinejad (2012) çalışmalarında üniversite öğrencilerinin spor aktivitelerindeki gönüllülük gerekçelerini sorgulamışlardır.

Tüm bu çalışmalardan ortaya çıkan sonuç gönüllülüğün bireylerin serbest zamanlarında yaptığ 1 bir eylem olduğudur.

Stebbins (1997) ciddi boş zaman faaliyeti olarak gönüllülük kavramının çoğunlukla gerçekleştirmek için özel bir yetenek, bilgi ve beceri gerektirmeyen, doğası gereği yapılması cazip, karlı, faydalı gözüken gündelik ve ciddi olmayan gönüllülükle (veya bir defalık yardımseverlikle) karıştırıldığını, gönüllülüğün ciddi boş zaman aktivitesi olabilmesi için sürekliliğinin ve bir kariyer beklentisiyle yapılıyor olması gerektiğini belirtmiştir. Bir defalık ya da düzenli tekrarı olmayan olaylarda veya düzenli destek verilmeyen durumlarda yapılan bireysel veya grup 
olarak gerçekleştirilen formel veya enformel organizasyonlarda yapılan gönüllülük faaliyeti serbest zaman faaliyeti olsa bile ciddi boş zaman faaliyeti olarak kabul edilmemelidir (Fischer \& Schaffer 1993; Stebbins \& Parker 1994; Stebbins 1996b). Tüm bu anlatımlardan sonra Stebbins'in (1992, 1996a, 1996b, 1997, 2004, 2013) Ciddi boş zaman faaliyeti olarak gönüllülüğü; özel bilgi, deneyim ve beceri gerektiren, bireyin tek başına ve/veya başkalarıyla formel veya enformel olarak örgütlenerek ilginç, önemli ve tatmin edici bulduğu bir misyonu gerçekleştirmek için, hiçbir karşl1ık beklemeden, herhangi bir zorlama ve yetkilendirme yapılmadan, tamamen kamu/başkalarının çıkarlarını gözeterek bireyin tamamen kendi istek ve arzularıyla, süreklilik arz edecek şekilde amatör, hobi ve gönüllü faaliyetlere kariyer beklentisi elde etmek ve bir yaşam biçimi oluşturacak şekilde belirlenmiş gönüllülük eylemine katılım göstermesi olarak tanımlamıştır.

Stebbins (1992) ciddi boş zaman faaliyeti olan gönüllülüğün temelinde sürekliliğin olduğunu ve sürekliliğin de; a) kişisel merak ve özgecilik davranışı içeren gönüllülük, b) özgeci ve/veya kişisel merak davranışıyla motive olunan kariyer beklentisiyle gönüllülük ve c) bireyin kişisel yetenek ve becerilerini kullandığg ve özel ödül beklentisiyle yapılan gönüllülük boyutlarında görüldüğü belirtmiştir.

Stebbins (1996b), Fischer ve Schaffer'in (1993) altı boyutta tanımladığı gönüllü olunarak elde edilen ödülleri/faydaları iki ayrı kategoride ve dokuz başlıkta özetlemiştir. Bunlar; "Kişisel Ödüller" kategorisi; a) müşteriler ve hizmet verilen kişilere olağan dışı muamelelerde bulunma, başkalarına yardım etme duygusu ve özgeci davranışlarda bulunma gibi "kişisel gelişme”, b) yetenek, beceri ve bilginin geliştirildiği "kendini gerçekleştirme", c) hali hazırda var olan yetenek, beceri ve bilginin gösterildiği "kendini gösterme", d) başkaları tarafından gönüllü olarak gösterilme ve bilinme gibi "kişisel imaj", e) hedonistik zevk, hareket etme ve oyun oynama duygusu yaşama gibi "kişisel iftihar/övünç", f) rekreatif beklentiler ve g) gönüllülükten finansal geri dönüşler, "Sosyal Ödüller" kategorisinde a) sosyal bir dünyaya dahil olunarak etkileşilen kişiler ve diğer gönüllülerle yaratılan "sosyal çekicilik", b) bir gruba dahil olunarak ve/veya bir grubun parçası olunarak yaratılan "ekip başarısı"dır.

Stebbins (1996a, 1996b) gönüllülüğü bir serbest zaman olarak algılayan yaklaşımların dışında gönüllülüğü; gündelik, ciddi olmayan ve sürekli tekrar eden biçimiyle ciddi boş zaman faaliyeti olarak üç farklı boyutta ele almıştır. Stebbins; gündelik ve ciddi olmayan gönüllülüğü "hevesli, laf olsun diye yapılan veya bir kerelik yapılan, bir işe heves duyup girişme eğiliminde bulunulan (dabbler)" olarak tanımlamışken, ciddi boş zaman faaliyeti olarak gönüllülüğü; "amatörler" (kazanç beklentisi olmadan daha çok profesyonellerle beraber/yakın olarak sporda, sanatta, bilimde veya eğlencede tatmin arayarak keyif aldıkları aktiviteleri yapan kişiler), "meraklılar" (daha çok profesyonelliğin ego yanını, bazı zamanlarda da ticari beklentiyle sporda, sanatta, bilimde veya eğlencede kolleksiyoner, tamirci veya üretici, rekabetçi olmayan aktiviteleri takip eden aktivite katılımcısı, profesyonel olmayan beklentilerle rekabetçi spor ve oyun etkinliklerini takip eden aktivite katılımcıları ve sosyal bilim katılımcıları olan kişiler) ve gönüllü olma boyutlarında gönüllü olmayı amatör ve meraklı olma boyutundaki yardımseverlik/gönüllülük eylemlerinden ayırt edip daha belirgin hale getirerek gönüllülüğü hiçbir karşılık beklemeden, kimsenin zorlaması olmadan, kişisel bir kariyer beklentisi ve her koşulda sürdüren kişilerin yaptığı “gönülülük” olarak yapılan aktiviteler toplamı olarak ele almıştır.

Stebbins (2004) ciddi boş zaman faaliyeti olarak gönüllülüğü altı kalite düzeyinde ele almış ve ciddi boş zaman faaliyeti olarak gönüllülüğü de bu parametrelerle tanımlamıştır. Birinci kalite düzeyinde; zorlukla yüzleşilen, sahne korkusunun yönetildiği, para ve zaman sıkıntısıyla uğraşıldığ1, çoğunlukla “azim ve sebat gerektiren gönüllülük” faaliyetleri, ikinci düzeyde; 
çoğunlukla bir dönüm noktası ve şansın güldüğü yere kadar sürdürülen, bireylerin başarma ve bağl1lıkla "kariyer için çabaladiğı gönüllülük" faaliyetleri, üçüncü düzeyde; şovmenlik, sportif kahramanlık, bilimsel bilgi ve uzun tecrübeye dayalı "özel bilgi, yetenek, beceri gerektiren ve o beceriye sahip kişiler tarafindan yapılan/yapılması gereken gönüllülük” faaliyetleri, dördüncü düzey; kendini gerçekleştirme, kendini zenginleştirme, kendini açıklama, kişisel yenileme/yenileştirme, başarma duygusunu yaşama, kişisel imaj yaratma ve geliştirme, sosyal ilişki kurma ve bir gruba ait olma, aktivitenin kalıcı fiziksel çıktılarına sahip olma/elde etme gibi "kalıcı fayda ve/veya çıktıyı ortaya koyan gönüllülük" faaliyetleri, beşinci düzey; bireyin kendisi ve başkalarıyla beraber tanımladığı, yarattığı ve sürdürdügü "emsalsiz bir dünya görüşüyle destekleyen yapıya başkalarının serbest zamanlarında dahil olduğu gönüllülük” faaliyetleri, altıncı düzey ise gündelik serbest zaman etkinliklerini dünyevi, geçici, aşağılayıcı, değersiz ve yaygın olarak kişilerin kendine ait bir değer bulduğu yapının karşıtı olarak kendini tanımladığı ve kimliğini bulduğu gönüllülük faaliyetleridir. AKUT örneği açısından bakıldığında bu altı kalite düzeyinin hepsinde gönüllü katılımını görmek mümkündür. Hatta özellikle Adana ve Marmara depreminden sonra oluşan AKUT imajı o dönemlerde ilkokuldaki çocuklara "büyüyünce ne olacaksın?" diye sorulduğunda “AKUT' '̧u olacağım” cevabı alınmaya başlanmıştı (Ardahan 2010).

AKUT’ta gönüllü olabilmek için öncelikle kişilik olarak AKUT'un misyonuna uygun bir birey olmak ve AKUT'ta bu konuda açılan eğitimlere katılmış olmak gereklidir. AKUT'un Dağ Arama Kurtarma Ekibi'ndekilerin mutlaka dağcı olması ve bu konudaki eğitimleri alması zorunlu iken AKUT'un Kentsel Arama Kurtarma Ekibindekiler uzmanlık alanına bağlı olarak deprem, sel veya yangın konularında ayrı ayrı veya birkaçı bir arada eğitimler alarak o konudaki operasyonlara katılabilecek formasyona sahip olurlar. Diğer bir deyişle; bir gönüllü sadece Dağ Arama Kurtarma Ekibi'nde olabileceği gibi diğer konulardaki eğitimleri de alarak Kentsel Arama Kurtarma Ekibi’nde de olabilir.

Gönüllü olmak birçok kişisel ve sosyal parametrenin etkilediği/etkilendiği bir davranış ve yaşam biçimidir. Wymer ve arkadaşları (1996) gönüllü olmayı ve/veya gönüllülüğü sürdürmeyi etkileyen dört boyut olduğunu ortaya koymuşlardır. Bunlar;

a) Kişilik, değerler, tutum ve davranışların etkilediği "kişisel faktörler",

b) Aile ve arkadaş çevresinin yapısı, etkileşilen/ait olunan toplumun öncelikleri, bireyin geçmiş deneyimleri, bireyin mevcut ilişkileri ve gelecekte olmayı istediği sosyal ağların belirlediği ve etkilediği "sosyal faktörler",

c) Bireyin işe yarayacak herhangi bir beceri ve yeteneğinin olup olmadığı veya yeni beceri ve yeteneklerin oluşması gibi "yararlı olabilme gücü”,

d) Bireyin gönüllü olmak ve gönüllülüğü sürdürmek için gerekli olan para, zaman, ulaşılabilirlik gibi faktörlerin veya somut ve psikolojik engellerin aşılmasını sağlayacak desteklerle "engellerin kaldırılacă̆ına/yok edileceğine olan inancının" olmasidir.

Bunlara ilave olarak Clary ve arkadaşları (1998) bireyin gönüllü olması ve sürdürmesinde etkili olan parametreleri altı boyutta ele almıştır. Bunlar; a) "değerler", b) bireyin sahip olduğu yetenek ve becerileri kullanabileceği, geliştirebileceği ve/veya yeni beceriler öğrenebileceği "gelişim ve ögrenme imkanları", c) bireyin diğer gönüllülerle ve başkalarıla yaratacağ "sosyalleşme firsatı", d) bireyin sosyal ve profesyonel hayatlarını etkileyebilecek "sosyal ve profesyonel kariyer beklentisi”, e) bireyin egosal bir yaklaşımla herhangi bir konuda kendi üstüne düşen görevi yerine getirdiğine dair inancın oluşması için "bireyin koruma ve sahip çıkma güdüsünü kullanması", f) bireyin herhangi bir durum/olay karşısında destekleyici veya karşıtlık içeren durumda "durulan tarafi güçlendirme" imkanı veriyor olmasıdır. 
Bunlardan başka gönüllü olmayı etkileyen diğer bazı parametreler ise demografik özelliklerdir. Burke ve Hall (1986), Lammers (1991), Sundeen (1992), yüksek gelir, eğitim düzeyi, iyi (saygın) işlerde ve işletmelerde çalışıyor olmanın gönüllülüğü olumlu etkilediğini, Rohs (1986), Berger (1991), Wymer ve arkadaşları (1996) yaşın, medeni durumun, çocuk sahibi olmanın, benzer bir deneyime sahip olmanın gönüllü olmayı ve sürdürmeyi etkilediğini ortaya koymuşlardır. Black ve DiNitto (1994) cinsiyetin gönüllü olmakta belirleyici olmadığını ortaya koysa da Ardahan (2011), Ibrahim ve Cordes (2002) rekreasyonel etkinliklere katılmada kadınların erkeklere oranla omuzlarına yüklenen roller gereği zamanlarının çok olmadığını bu sebeple gönüllülük için de çok fazla zaman ayıramayacaklarını belirtmişlerdir.

Diğer birçok STK gönüllüsü olan bireyler gibi AKUT Kent Operasyon Ekibi’nde gönüllü olanlar da ciddi boş zaman faaliyeti olarak gönüllülüğü yaşamak için vardırlar ve Ardahan'ın (2015a) yaptığı çalışmada bireylerin AKUT'ta gönüllü olma ve gönüllülüğü sürdürme gerekçelerinin faktör analizi yapılmış ve elde edilen faktörler aşağıda verilmiştir;

- Bireylerin onayladığı bir misyonu desteklemesi ve onun gerçekleşmesi için çaba sarf etmesini tarifleyen unsurlardan oluşan "Bir Misyonu Onaylama” faktörü.

- Bireylerin AKUT'a dahil olarak kendilerini değerli hissetmesi, kendine güven duyması ve başarmayı tarifleyen unsurlardan oluşan "Değerli Hissetme/Başarma" faktörü.

- Bireylerin AKUT'a dahil olarak yenilenmeyi ve yeni olanı deneyimlemeyi tarifleyen unsurlardan oluşan "Yenileme/Yenilenme" faktörü.

- Bireylerin AKUT'a dahil olarak aile bireyleri ve çevresindeki diğer bireylere örnek olmayı tarifleyen unsurlardan oluşan “Örnek Olma” faktörü. .

- Bireylerin AKUT'a dahil olarak sahip oldukları yetenek ve becerileri kullanabilmeleri ve toplumda bir işe yarama duygusunu tarifleyen unsurlardan oluşan "Becerileri Kullanma/İşe Yarama” faktörü.

- Bireylerin AKUT’a dahil olarak bir gönüllülük eyleminde bulunmalarını, bunu deneyimlemeyi ve bunu deneyimleyen diğerleriyle birlikte olmayı tarifleyen unsurlardan oluşan “Gönüllülüğ̈̈ Yaşama” faktörüdür.

Bu çalışmanın amacı ciddi boş zaman faaliyeti olarak gönüllülüğü AKUT örneğinde ele alıp AKUT’un gönüllü profilini belirlemektir.

\section{Yöntem}

Araştırma Modeli ve Sınırlılık: Araştırma tanımlayıcı bir araştırmadır ve bu çalışma AKUT Kentsel Operasyon Ekibinde gönüllü olan bireylerle sınırlıdır.

Örneklem Süreci, Veri Toplama Aracı ve Değişkenler: Araştırmanın veri uzayı ve örneklemi kurulduğu 1996 yılından bu yana dağ ve doğa koşullarında oluşan kaybolma ve kaza olaylarına müdahale etmenin yanında sel, deprem gibi doğal afetlerde ve büyük kazalarda, tamamen gönüllü olarak arama ve kurtarma misyonuyla kurulan ve bu misyonu sürdüren AKUT'un Kentsel Operasyon Ekibinde yer alan toplam 420 kişiden oluşmaktadır.

$\mathrm{Bu}$ çalışmada veri toplama aracı olarak elektronik anket formu kullanılmıştır. Elektronik anket formu AKUT merkez ofis aracılığıyla operasyon ekibine doldurulması ricasıyla 1 Ocak 2015-1 Mart 2015 tarihleri arasında 20'şer gün arayla gönderilmiş; cevaplanan ve veriler arasında tutarlılı̆̆ olan 208 anket değerlendirmeye alınmıştır. Elektronik anket formu demografik bilgilerin yanında; Ardahan (2015a) tarafından 2015 yılında geliştirilen AKUT'ta Gönüllü Olma Ölçeği'ne (AGOÖ) yer verilmiştir. Çalışmada beşli Likert ölçeği (1-Kesinlikle Katılmıorum,..., 5-Kesinlikle Katılıyorum) kullanılmıştır. 
Verilerin Analizi: Verilerin analizinde tanımlayıcı istatistiksel yöntemlerin yanında, normal dağılım koşulları yerine gelen karşılaştırmalar için Independent Samples Test (t), One Way ANOVA testi (F), normal dağılım koşullarının yerine gelmediği karşılaştırmalar için MannWhitney $U(Z)$ testi gruplar arasındaki farkın belirlenmesinde Tukey-b testi kullanılmış ve sonuçlar 0.05 anlamlılık düzeyinde değerlendirilmiştir.

AGOÖ’nün Güvenirlilik değerleri; AGOÖ’nün toplam Cronbach's Alpha değeri 0,930'dur. Elde edilen faktörler, "Bir Misyonu Onaylama, Cronbach's Alpha değeri = 0,926", "Değerli Hissetme/Başarma, Cronbach's Alpha değeri = 0,904", "Yenileme/Yenilenme, Cronbach's Alpha değeri $=0,876 "$, "Beceri Kullanma/İșe Yarama, Cronbach's Alpha değeri = 0,833", "Örnek Olma, Cronbach's Alpha değeri = 0,781" ve "Gönüllülüğü Yaşama, Cronbach's Alpha katsay1s1 $=0,712$ "

\section{Bulgular}

AKUT gönüllülerinin demografik bilgileri Tablo-1'de verilmiştir. Tablodan da görülebileceği gibi; gönüllülerin \%77,9'u erkek, \%73,1'i 40 yaş ve alt1, \%56,7'si bekar, \%77,9'u üniversite ve üstü eğitime sahip, \%52,9'u kamu ve özel sektörde çalışmakta, \%76,9'u AKUT'a dahil olmaya kendisi karar vermiş, \%53,8'i 2001 TL ve üstü gelire sahip, \%47,1'inin kısmen, \%46,2'sinin ise tam anlamıyla gönüllülük hakkında bilgisi var, \%39,4'ünün ailesinde kendinden başka gönüllü vardır ve ailedeki diğer gönüllülerin \%46,3'ü eşleridir. Katılımcılar ortalama 5,73 \pm 5,22 yıldır gönüllülük faaliyeti içindedirler ve haftada ortalama gönüllülük faaliyeti için ortalama 7,19 \pm 4,02 saat ayırmaktadırlar. Gönüllüler günlük ortalama 2,01 $\pm 1,38$ saat TV izlerken, en son sinemaya 17,12 $\pm 33,21$ hafta önce gitmişler ve en son kitaplarını da 13,09 $\pm 24,77$ gün önce okumuşlardır. TV'de ağırlıklı olarak Haber ve Belgesel programları izlerlerken MagazinEğlence, Dizi ve Müzik programlarını izlememektedirler. Bu veriler içerisinde en çarpıcı olan kısım AKUT'un operasyon ekibindeki kişilerin eşlerinin de gönüllü olmaları, gönüllülük hakkında bilgili olmaları ve TV'de izlenen programların genel reyting dışı programlar olmasidir.

Tablo 1. Kat1limcilara Ait Demografik Veriler

\begin{tabular}{lcc}
\hline Demografik Değişkenler & n & \% \\
\hline (Y1) 30 yaş ve altı & 80 & 38,5 \\
(Y2) 31-40 yaş & 72 & 34,6 \\
(Y3) 50 yaş & 36 & 17,3 \\
(Y4) 51 yaş ve üstü & 20 & 9,6 \\
\hline (G1) 1000 TL ve Altı & 40 & 19,2 \\
(G2) 1001-2000 TL & 56 & 26,9 \\
(G3) 2001-3000 TL & 60 & 28,8 \\
(G3) 3001 TL ve üstü & 52 & 25,0 \\
\hline Okuldaki hocalarımın etkisi & 2 & 1,0 \\
Aile Bireylerinin etkisi & 14 & 6,7 \\
İş/Okul arkadaşlarımın etkisi & 22 & 10,6 \\
Sosyal yaşamdaki arkadaşlarım & 56 & \\
etkisi & & 26,9 \\
Medyadaki paylaşımların etkisi & 34 & 16,3 \\
Kendim karar verdim & 160 & 76,9 \\
\hline Haber & 150 & 72,1
\end{tabular}

\begin{tabular}{lcc}
\hline Demografik Değişkenler & n & $\mathbf{\%}$ \\
\hline Özel Sektör & 64 & 32,7 \\
Kamu Sektörü & 42 & 20,2 \\
Serbest Meslek & 8 & 3,8 \\
Kendi İşim & 30 & 14,4 \\
Emekli & 14 & 6,7 \\
Öğrenci & 40 & 19,2 \\
İşsiz & 6 & 2,9 \\
\hline (E1) Lise Dengi ve Altı & 46 & 22,1 \\
(E2) Üniversite ve Üstü & 162 & 77,9 \\
\hline Gönüllülük hakkında bilgi Evet & 96 & 46,2 \\
Gönüllülükhakkındabilgi Kısmen & 98 & 47,1 \\
Gönüllülük hakkında bilgi Hayır & 14 & 6,7 \\
& & \\
\hline Toplam & $\mathbf{2 0 8}$ & $\mathbf{1 0 0 , 0}$ \\
\hline Ailede Başka Gönüllü var mı? & $\mathbf{n}$ & $\mathbf{9}$ \\
\hline Evet & 82 & 39,4
\end{tabular}




\begin{tabular}{|c|c|c|c|c|c|}
\hline Belgesel & 144 & 69,2 & Hayır & 126 & 60,6 \\
\hline Sinema & 116 & 55,8 & Ailedeki Diğer Gönüllüler & $\mathbf{n}$ & $\%$ \\
\hline Kültür-Sanat & 78 & 37,5 & Eş & 38 & 46,3 \\
\hline Spor & 68 & 32,7 & Anne & 12 & 14,6 \\
\hline Açık oturum-Tartışma & 64 & 30,8 & Baba & 4 & 4,9 \\
\hline Yarışma & 60 & 28,8 & Kardeş & 14 & 17,1 \\
\hline Dizi & 42 & 20,2 & Evlat/Çocuk & 14 & 17,1 \\
\hline Müzik & 34 & 16,3 & Toplam & 82 & 100,0 \\
\hline Magazin-Eğlence & 16 & 7,7 & Ortalama Değerler & \multicolumn{2}{|c|}{$\mathrm{X} \pm \mathrm{SS}$} \\
\hline (E)Erkek & 162 & 77,9 & Kaç Yıldır Gönüllüsünüz & \multicolumn{2}{|c|}{$5,73 \pm 5,22$} \\
\hline (K)Kadın & 46 & 22,1 & Gönüllülüğe ayrilan süre (hafta/saat) & \multicolumn{2}{|c|}{$7,19 \pm 4,02$} \\
\hline (E)Evli & 90 & 43,3 & En son kitap okuma (gün önce) & \multicolumn{2}{|c|}{$12,80 \pm 23,74$} \\
\hline (B)Bekar & 118 & 56,7 & Sinemaya gitme (kaç hafta önce) & \multicolumn{2}{|c|}{$17,12 \pm 33,21$} \\
\hline Toplam & 208 & $\overline{100,0}$ & Günlük TV izleme (saat) & \multicolumn{2}{|c|}{$2,01 \pm 1,38$} \\
\hline
\end{tabular}

AKUT gönüllülerinin serbest zamanlarında yaptıkları sportif ve spor dışı rekreatif etkinlikler Tablo-2'de verilmiştir. Tablodan da görülebileceği gibi AKUT operasyon ekibinin \%078,8'i dağcılık, kaya tırmanma, doğa yürüyüşü, dağ ve yol bisikleti gibi katılımcı ile doğa arasında etkileşimli olarak doğal ve/veya yapılandırılmış açık alanlarda yapılan sporlarla uğraşırlarken, \%754'ü spor dışı etkinlikler olarak Arkadaşlarla birlikte olmak, Konsere gitmek, Aile ile birlikte olmak gibi öncelikleri vardır. Katılımcıların çok azı Hava sporları, Raket sporları ve Mücadele sporlarıyla ilgililerken, spor dışı zamanlarında da daha çok aktif olmayı seçmektedirler.

Tablo 2. Katılımcıların Serbest Zamanlarında Yaptıkları Aktiviteler

\begin{tabular}{lcc}
\hline Serbest Zamanlarda Yapılan Sportif Etkinlikler & n & \% \\
\hline Doğa Sporları (Dağcılık, kaya tırmanma, doğa yürüyüşü, dağ ve yol bisikleti gibi & & 78,8 \\
katılımcı ile doğa arasında etkileşimli olarak doğal ve/veya yapılandırılmış açık & 82,0 & 33,7 \\
alanlarda yapılan sporlar) & 35,0 & 21,2 \\
Su Sporları (Yüzme, yelken, kano gibi & 22,0 \\
Fitness Merkezlerinde Yapılan Sporlar (Fitness, Step Aerobik, Plates, Squash gibi) & 18,3 \\
Parklardaki rekreatif spor aktiviteleri (Park spor araçları, parkta yürüme ve koşmi & 16,3 \\
gibi) & 19,0 \\
Takım Sporları (Futbol, basketbol, voleybol gibi & 17,0 \\
Motor Sporları (Motokros, off road gibi) & 13,0 \\
Ferdi Sporlar (Okçuluk, atletizm gibi) & 12,0 \\
Halk oyunları ve danslar (Yerli ve yabancı oyunlar ve danslar) & 12,5 \\
Hava Sporları (Serbest paraşüt, Yamaç paraşütü, Yamaç dalışı gibi) & 11,5 \\
Raket Sporları (Tenis, Badminton gibi) & 8,0 \\
Mücadele Sporları (Güreş, Karete, Taekwondo gibi) & 9,6 \\
\hline Serbest Zamanlarda Yapılan Spor Dışı Etkinlikler & 7,0 \\
\hline Arkadaşlarla birlikte olmak & 6,0 \\
Konserlere gitmek & $\mathbf{n}$ & 5,7 \\
Aile ile birlikte olmak & n \\
İnternette gezinmek & 74,0 \\
Sinemaya gitmek & 71,0 & 71,2 \\
\hline
\end{tabular}


Sosyal medyada olmak

$45,0 \quad 43,3$

TV-Video-Film izlemek

$42,0 \quad 40,4$

Tiyatroya gitmek

$37,0 \quad 35,6$

Alış verişe çıkmak

$21,0 \quad 20,2$

Evde dinlenmek

19,0

18,3

Bireylerin AKUT’ta gönüllü olma sebebi olmayan maddeler Tablo-3’te verilmiştir. Tablodan da görülebileceği gibi bireyler aileden, günlük sorumluluklardan, arkadaş çevresinden uzaklaşmak, mutlu olmak, iyi vakit geçirmek, sosyalleşmek, sevgili (partner) bulmak gibi sebeplerden dolayı AKUT'ta değillerdir. Bireylerin AKUT'ta olma sebepleri daha çok üst düzeyli toplumsal değerlerden oluşurken kişisel egoya hitap eden unsurlardan uzaktır. Bu da AKUT'un gönüllülerini seçerken ne kadar doğru bir seçim süreci ortaya koyduğunu gösterir. Diğer bir deyişle bu durum kendisine kişisel çıkar temin edecek bireyler yerine gücünü, enerjisini, yetenek ve becerisini AKUT'un misyonunu gerçekleştirmek için kullanacak bireylerin kuruma alınması, orada gönüllülüğünü sürdürmesini sağlamaktır.

AGOÖ’nün faktörlerinin demografik değiş̧kenlerle karşılaştırılması Tablo-4'te verilmiştir. Tablodan da görülebileceği gibi faktörlerin demografik değişkenlerle karşılaştırılmasında "Bir Misyonu Onaylama" faktöründe cinsiyete göre erkeğin lehine, "Yenileme/Yenilenme" faktöründe yaş (30 yaş ve altı katılımcıların lehine) ve eğitime göre (üniversite ve üstü eğitim düzeyine sahip olanların lehine), "Örnek Olma" faktöründe gelir (1000 TL ve altı gelire sahip olanların aleyhine), cinsiyet (erkeğin lehine) ve medeni durumda (evlinin lehine) gruplar arasında istatistiki olarak anlamlı fark vardır. Faktörlerin demografik değişkenlere göre çok fazla farklılık vermiyor olması AKUT'ta gönüllülüğün demografik değişkenlere göre değişmediğini her özellikten bireyin o misyonu iyi anladığı, iyi taşıdığı ve içselleştirdiği anlamına gelir.

Tablo-3: Katılımcıların AKUT’ta Gönüllü Olma Sebebi Olmayan Maddeler

\begin{tabular}{lcc}
\hline AKUT’ta Gönüllü Olma Sebebi Olmayan Maddeler & X & SS \\
\hline Günlük rutinden bir süreliğine uzak kalmak için & 2,49 & 1,33 \\
Beni mutlu ettiği için & 2,47 & 0,57 \\
Boş zamanımı daha etkin kullanmak için & 2,38 & 0,61 \\
Beni cezbeden işleri yapabildiğim ve mekânlara gidebildiğim için & 2,37 & 1,30 \\
Sosyal bir statü sağladığını düşündüğüm için & 2,36 & 1,19 \\
Gönüllülük beğendiğim ve etkilendiğim bir şey olduğu için & 2,32 & 0,66 \\
İyi vakit geçirdiğim için & 2,24 & 0,70 \\
Hayatıma yeni bir boyut kazandırmak için & 2,17 & 0,72 \\
Gönüllü olmak kariyerime destek sağladığı/sağlayacağı için & 2,08 & 1,21 \\
Bir gruba ait olmak istediğim için & 2,07 & 0,77 \\
Günlük yaşantımdaki dedikodu ve söylentilerden uzak olmak için & 2,06 & 0,80 \\
İş dışındaki sosyal grup arkadaşlarımla birlikte olmak için & 2,01 & 0,74 \\
Sosyalleşmek için & 1,97 & 0,75 \\
Başkaları tarafından takdir edilmek için & 1,96 & 1,10 \\
İşten/okuldan bir süreliğine uzak kalmak için & 1,91 & 1,30 \\
İş arkadaşlarım ile birlikte olmak için & 1,83 & 1,00 \\
Başkalarını etkilemek için & 1,78 & 1,09 \\
Başkaları tarafından tanınmak ve beğenilmek için & 1,75 & 0,99
\end{tabular}


Yalnızlıktan kurtulmak için

Ailemden bir süreliğine uzak kalmak için

Arkadaşlarım gönüllü olmamı istediği için

Etrafımdaki insanlardan uzaklaşmak için

Günlük yaşamın sorumluluklarımdan kurtulmak için

Şu anda yapabileceğim başka hiçbir etkinlik olmadı̆̆

Yeni bir partner (sevgili) bulmak için

$\begin{array}{ll}1,64 & 0,89 \\ 1,58 & 1,05 \\ 1,57 & 1,04 \\ 1,76 & 0,98 \\ 1,79 & 1,00 \\ 1,46 & 0,71 \\ 1,37 & 0,80\end{array}$

1-Kesinlikle Katılmıyorum, 2-Katılmıyorum, 3-Kısmen Katılıyorum, 4-Katılıyorum, 5-Kesinlikle Katılıyorum

Erkeklerin "bir misyonu onaylama" faktör puanının kadınlara göre daha fazla destekleniyor olması erkeklerin STK'lar içinde daha çok rol almayı istemelerinden kaynaklanıyor olabilir. Bunun yanında yaşları 30 ve altında olanların kendilerini yenilemeleri, yeni beceriler öğrenme ve kendilerini geliştirmeleri ve farkın onların lehine çıkması bireylerin bu yaşlarda büyük ölçüde gelişim sürecinde olmalarından, öğrencilerin henüz gelişim sürecinden olmalarından ve bu yaş grubu bireylerin \%50'sinin öğrenci olmasından kaynaklanıyor olabilir. Örnek olma sahip olunan birikimle (yetenek, beceri, bilgi) çok yakından ilgilidir. Bu birikime yapılan nitelikli yatırımla ulaşılacağı gerçeği bu yatırımın zamanla ve yaşla ilgisi olmadığını burada göstermiştir. Yaş gruplarına göre farklılı̆̆ın istatistiki olarak anlamlı olmaması bunun göstergesidir. Bunun yanında G1 düzeydeki gelire sahip bireylerin $\% 65$ 'inin öğrenci olması ve öğrencilerin de kendilerini örnek olmak için henüz yeterli görmemeleri normal kabul edilebilir. Erkeklerin kadınlara göre örnek olmalarının Türk toplumunda erkeğe yüklenen misyonla ilgisinin olabileceği gibi, evlilerin bekarlara göre daha fazla örnek olma davranışı ebeveyn olmanın sorumluluğundan kaynaklanabilir.

Tablo 4. AGOÖ Faktörlerinin Demografik Değişkenlerle Karşılaştırılması

\begin{tabular}{|c|c|c|c|c|c|}
\hline AGOÖ Faktörleri & Yaş & Gelir & Cinsiyet & Med. Dur. & Eğitim \\
\hline $\begin{array}{l}\text { Bir Misyonu } \\
\text { Onaylama }\end{array}$ & $\begin{array}{l}Y 1=4,30 \pm 0,93 \\
Y 2=4,21 \pm 0,80 \\
Y 3=4,62 \pm 0,63 \\
Y 4=4,40 \pm 0,45 \\
F=2,144\end{array}$ & $\begin{array}{l}\mathrm{G} 1=4,10 \pm 1,00 \\
\mathrm{G} 2=4,23 \pm 0,76 \\
\mathrm{G} 3=4,46 \pm 0,72 \\
\mathrm{G} 4=4,49 \pm 0,77 \\
\mathrm{~F}=2,581\end{array}$ & $\begin{array}{l}E=4,37 \pm 0,86 \\
K=4,20 \pm 0,61 \\
Z=-\mathbf{2 , 8 7 1} *\end{array}$ & $\begin{array}{l}E=4,31 \pm 0,74 \\
B=4,35 \pm 0,86 \\
t=-0,279\end{array}$ & $\begin{array}{l}E 1=42,33 \pm 0,59 \\
E 2=4,34 \pm 0,87 \\
Z=-1,249\end{array}$ \\
\hline $\begin{array}{l}\text { Değerli Hissetme } \\
\text { /Başarma }\end{array}$ & $\begin{array}{l}Y 1=3,44 \pm 1,00 \\
Y 2=3,27 \pm 0,86 \\
Y 3=2,98 \pm 1,15 \\
Y 4=3,33 \pm 0,85 \\
F=1,935\end{array}$ & $\begin{array}{l}\text { G1 }=3,11 \pm 1,06 \\
\text { G2 }=3,37 \pm 0,78 \\
\text { G3 }=3,50 \pm 0,99 \\
\text { G4 }=3,12 \pm 1,06 \\
F=2,049\end{array}$ & $\begin{array}{l}E=3,29 \pm 1,01 \\
K=3,29 \pm 0,86 \\
Z=-0,050\end{array}$ & $\begin{array}{l}E=3,22 \pm 0,87 \\
B=3,35 \pm 1,05 \\
t=-0,971\end{array}$ & $\begin{array}{l}E 1=3,11 \pm 0,98 \\
E 2=3,34 \pm 0,97 \\
Z=-1,629\end{array}$ \\
\hline Yenileme/Yenilenme & $\begin{array}{l}Y 1=3,25 \pm 1,09 \\
Y 2=2,67 \pm 0,94 \\
Y 3=2,36 \pm 1,07 \\
Y 4=2,50 \pm 0,91 \\
\mathbf{F}=\mathbf{8 , 4 4 4} *\end{array}$ & $\begin{array}{l}\text { G1 }=3,10 \pm 1,15 \\
\text { G2=2,74 } \pm 0,94 \\
\text { G3 }=2,98 \pm 1,14 \\
\text { G4 }=2,52 \pm 1,00 \\
F=2,949\end{array}$ & $\begin{array}{l}E=2,83 \pm 1,04 \\
K=2,77 \pm 1,18 \\
Z=-0,289\end{array}$ & $\begin{array}{l}E=2,63 \pm 1,02 \\
B=2,97 \pm 1,09 \\
t=-2,254\end{array}$ & $\begin{array}{l}E 1=2,53 \pm 1,11 \\
E 2=2,90 \pm 1,05 \\
\mathbf{Z}=\mathbf{- 1 , 9 5 9 *}\end{array}$ \\
\hline Örnek Olma & $\begin{array}{l}Y 1=3,14 \pm 1,35 \\
Y 2=3,50 \pm 0,99 \\
Y 3=3,36 \pm 1,37 \\
Y 4=3,50 \pm 0,83 \\
F=1,312\end{array}$ & $\begin{array}{l}\text { G1 }=2,60 \pm 1,48 \\
\text { G2 }=3,55 \pm 1,03 \\
\text { G3 }=3,50 \pm 1,01 \\
\text { G4 }=3,48 \pm 1,15 \\
\mathbf{F}=\mathbf{6 , 7 7 0} *\end{array}$ & $\begin{array}{l}E=3,43 \pm 1,18 \\
K=3,00 \pm 1,23 \\
Z=-\mathbf{2 , 1 7 9} *\end{array}$ & $\begin{array}{l}E=3,54 \pm 0,96 \\
B=3,18 \pm 1,34 \\
t=2,297 *\end{array}$ & $\begin{array}{l}E 1=3,37 \pm 1,24 \\
E 2=3,33 \pm 1,19 \\
Z=-0,192\end{array}$ \\
\hline
\end{tabular}




\begin{tabular}{llllll}
\hline \multirow{3}{*}{$\begin{array}{l}\text { Becerileri Kullanma } \\
\text { /Işse Yarama }\end{array}$} & $\mathrm{Y} 1=3,82 \pm 1,03$ & $\mathrm{G} 1=3,68 \pm 1,25$ & $\mathrm{E}=3,79 \pm 0,99$ & $\mathrm{E}=3,77 \pm 0,93$ & $\mathrm{E} 1=4,00 \pm 0,71$ \\
& $\mathrm{Y}=3,81 \pm 0,85$ & $\mathrm{G}=3,83 \pm 0,66$ & $\mathrm{~K}=3,87 \pm 0,93$ & $\mathrm{~B}=3,84 \pm 1,02$ & $\mathrm{E} 2=3,75 \pm 1,04$ \\
& $\mathrm{Y} 4=4,07 \pm 0,57$ & $\mathrm{G} 3=3,89 \pm 0,96$ & $\mathrm{Z}=-0,483$ & $\mathrm{t}=-0,480$ & $\mathrm{Z}=-1,068$ \\
& $\mathrm{~F}=0,869$ & $\mathrm{~F}=0,375$ & & & \\
\hline \multirow{3}{*}{ Gönüllülüğü Yaşama } & $\mathrm{Y} 1=3,63 \pm 0,96$ & $\mathrm{G} 1=3,45 \pm 0,92$ & $\mathrm{E}=3,49 \pm 0,92$ & $\mathrm{E}=3,39 \pm 0,77$ & $\mathrm{E} 1=3,32 \pm 0,98$ \\
& $\mathrm{Y} 2=3,37 \pm 0,90$ & $\mathrm{G} 2=3,48 \pm 0,82$ & $\mathrm{~K}=3,42 \pm 0,93$ & $\mathrm{~B}=3,55 \pm 1,02$ & $\mathrm{E} 2=3,52 \pm 0,90$ \\
& $\mathrm{Y3}=3,24 \pm 0,95$ & $\mathrm{G} 3=3,59 \pm 1,03$ & $\mathrm{Z}=-0,576$ & $\mathrm{t}=-1,311$ & $\mathrm{Z}=-1,164$ \\
& $\mathrm{Y} 4=3,70 \pm 0,66$ & $\mathrm{G} 4=3,37 \pm 0,91$ & & & \\
& $\mathrm{~F}=2,226$ & $\mathrm{~F}=0,528$ & & & \\
\hline
\end{tabular}

$* \mathrm{p}<0.05$

\section{Tartışma ve Sonuç}

Bu çalışmada ciddi boş zaman etkinliği olarak gönüllülük AKUT örneğiyle ele alınıp, Kentsel Operasyon Ekibinin profiline yer verilmiştir.

Rohs (1986), Berger (1991), Wymer ve arkadaşları (1996) ve yaptıkları çalışmada bireyi gönüllü olmaya motive eden sosyal değişkenler üzerinde durulmuştur. Bunlardan ilki; gönüllülük ve medeni durum arasındaki ilişkidir. Evli olmanın gönüllülük üzerinde önemli bir etkisinin olduğu ortaya konmuştur. Mevcut çalışmada katılımcıların önemli bir kısmının evli olması Wymer ve arkadaşlarının, Rohs'un ve Berger'in sonuçlarıyla örtüşmektedir. Bunun yanında, Berger'e (1991) göre bekar olan bireyler gönüllü olmaları durumunda gönüllülük için daha çok ve evli olanların da daha uzun zaman harcayabileceklerdir. Aralarında istatistiki olarak

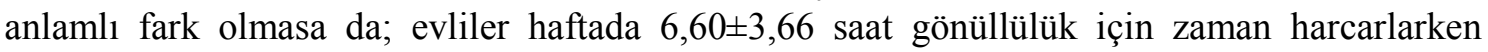
bekarlar 7,64 $\pm 4,22$ saat zaman harcamaktadırlar. Bunun yanında; bekarlar 4,68 $\pm 3,42$ yıldır AKUT'ta gönüllü iken evliler 7,11 $\pm 6,66$ yıldır gönüllüdürler ve bu farklılık istatistiki olarak anlamlıdır $(\mathrm{t}=3,424, \mathrm{p}=0,01)$. Bu sonuçlar Berger'in ve Wymer ve arkadaşlarının sonuçlarıyla örtüşmektedir. Bunun yanında Perkins (1989) ve Bequette (1990) gönüllülüğün aslında sosyal bir etkileşim olduğunu okul veya sosyal dünyadaki arkadaşların, aile çevresinin gönüllü olmada etkisinin olduğunu, gönüllü olabilmek için aslında ihtiyaç duyulanın küçük bir koçluk davetiyle bireyin bu dünyaya çekilmesi olduğunu tanımlamışlardır. Mevcut araştırma sonuçları da büyük ölçüde bunu destekler niteliktedir. Her ne kadar AKUT gönüllüleri büyük ölçüde gönüllü olmaya kendileri karar verseler de aile bireyleri, iş, okul ve sosyal yaşamdaki arkadaşlarının etkisiyle gönüllü olanların oranı oldukça yüksektir. Buna ilave olarak gönüllülerin önemli bir kısmında ailesinde kendinden başka gönüllü olanların olması, gönüllü olanların da büyük oranda eş olması Perkins ve Bequette'in çalışmalarıyla örtüşmektedir.

Ciddi boş zaman etkinliği olarak gönüllülük faaliyetine katılanların gönüllülüğün ne olduğunu, sorumlulukların neler olduğu hakkında bilgili olması gerekir. AKUT gönüllülerinin de AKUT’ta gönüllü olmadan önce gönüllülük hakkında bilgi sahibi olmaları beklenen bir durumdur.

İbrahim ve Cordes (2002) ve Ardahan'ın (2011) çalışmalarında belirttikleri gibi kadınların annelik rolü, çalışan rolü, evdeki ev kadınlığı rolü gibi birçok nedenden dolayı hem rekreasyonel aktivitelere, hem de doğa sporlarına yoğun katılamaması, doğa sporlarının erkek hegemonyasında olmasına neden olmaktadır. Bu sebeple benzer yapı erkeklerin kadınlara göre AKUT'ta daha çok olmasına sebep olmuş olabilir. Mevcut çalışmadaki sonuçlar literatürdeki sonuçlarla örtüşmektedir. Bunun yanında AKUT'un hem Dağ hem de Kentsel Operasyon Ekibi büyük ölçüde dağcılardan oluştuğu için, ki mevcut çalışmada da sonuçlar bu şekilde bulunmuştur, fiziksel yeterliliği olan bireylerden oluşması ve bunların da her koşulda uzun süre operasyon yapabilecek fiziksel yeterlilikte olması zorunluluğu ekibin yaşça gençlerden ve fiziksel yeterliliği olacak yaştakilerden oluşması gereklidir. Mevcut çalışmanın sonuçları Ardahan'ın 
(2011) sonuçlarıyla örtüşmektedir.

Burke and Hall (1986), Lammers (1991), Sundeen (1992), Wymer ve arkadaşları (1996) yaptıkları çalışmada gönüllülüğün bir bilinç meselesi olduğunu bunun da eğitimle, iyi (saygın) işlerde ve işletmelerde çalışıyor olmakla yakından ilişkili olduğunu, gönüllülerin gönüllü olmayanlara göre daha iyi eğitim düzeyine sahip olduklarını ve daha iyi işlerde ve pozisyonlarda çalıştı̆̆ını belirtmişlerdir. Bahsedilen bu sonuçlar mevcut araştırma sonuçlarıyla büyük ölçüde benzeşmektedir. Benzer durum gönüllülüğün gelirle olan ilişkisidir. Daha çok emek ve zaman harcayarak gönüllü olanların orta gelir düzeyindeki bireyler olduğu (Burke \& Hall, 1986; Perkins 1989; Bequette 1990; Lammers, 1991; Sundeen 1992; Wymer et al. 1996), gelir arttıkça daha çok para desteğinde bulunarak bireylerin gönüllülük çalışmalarına katıldıkları bulgusu mevcut araştırmanın sonuçlarıyla örtüşmektedir.

Katılımcıların serbest zamanlarında yaptıkları hem sportif aktiviteler hem de spor dışı etkinlikler Ardahan'ın $(2013 ; 2015$ b) yaptığ 1 çalışmalarda normal bireylerin yaptıkları etkinlikten farklıdır. Ardahan'ın çalışmasındaki bireyler daha çok pasif rekreasyonel aktiviteleri ve takım oyunlarını tercih ederlerken, AKUT gönüllüleri daha çok aktif katılımlı etkinlikleri ve doğa sporlarını tercih etmektedirler.

Bunlara ilave olarak, Ardahan (2011; 2013; 2015b), İbrahim ve Cordes’in (2002) çalışmalarinda bulgulanan ve bireylerin rekreasyonel aktiviteye katılmasında belirleyici nedenlerden olan " $t$ ", "bir gruba ait olma isteğgi”, "sosyalleşme isteği”, "arkadaşlarla birlikte olma isteğì,, “yalnızlıktan kurtulma” gibi gerekçeler AKUT Kentsel Operasyon Ekibinin AKUT’ta gönüllü olmaları için etkili olmayan (belirleyici olmayan) faktörler içinde yer almaktadır. Bu da bireylerin gönüllülüğü sadece serbest zamanlarda yapılan bir etkinlik olarak görmeyip ciddi boş zaman faaliyeti olarak gördüklerinin göstergesidir.

Bunlara ilave olarak bireylerin AKUT’un Kentsel Operasyon Ekibi'nde gönüllü olmasını etkileyen faktörlerin çeşitli demografik değişkenlerle karşılaştırılmasında neredeyse her grupta benzer bir homojenlikte olması AKUT misyonunun bireyler tarafından iyi algılandığı, AKUT'un gönüllü seçimi ve yönetimi sürecinde başarılı olduğu söylenebilir. "Bir Misyonu Onaylama" faktöründe erkeklerin kadınlara göre daha çok ortalamaya sahip olmalarının temelinde erkeklerin STK yönetimlerinde, Yerel Yönetime katılmada kadınlara oranla daha çok rol üstlenmelerinden kaynaklanabilir. Bu sonuç Alkan (1989, 127), Özdemir ve diğerleri (2009), İğci (2008) ve Ardahan'ın (2014) çalışmalarıyla örtüşmektedir. Bunun yanında "Yenileme/ Yenilenme" arzusu ile AKUT'ta gönüllü olma ve gönüllülüğü sürdürme bireylere AKUT'un ciddi anlamda bir yatırım yaptığını göstermektedir. "Örnek Olma" faktöründe gelir arttıkça bireylerin daha çok örnek olmak için gönüllülüğü sürdürmeleri Ibrahim ve Cordes’te (2002) detaylı ele alınan Maslow'un İhtiyaçlar Hiyerarşisindeki üst düzeyli ihtiyaçların tatminine örnek olacak niteliktedir. Erkeklerin kadınlara göre, evlilerin de bekarlara göre daha yüksek örnek olma davranışı içinde olmaları üstlenilen rollerle ilişkili olabilmektedir. Bu sonuçlar Özdemir ve diğerleri (2009) ve Ardahan'ın (2013) çalışmalarıyla benzeşmektedir.

Sonuç olarak, AKUT'un Kentsel Operasyon Ekibi’nde gönüllü olan bireylerin önemli bir kısmı, doğa sporlarıyla aktif olarak ilgilenmekteler, spor dışı aktiviteleri olarak; arkadaşlarıyla ve ailesiyle birlikte olmakta, konserlere gitmekteler. Bunlara ilave olarak gönüllü bireylerin büyük çoğunluğu; erkek, bekâr, çalışır durumda, 40 yaş ve altında, 3000 TL ve altında aylık gelire, üniversite ve üstü eğitime sahiptirler. Yaklaşık altı yıldır AKUT'ta gönüllü olan bu bireyler AKUT’ta gönüllü olmadan önce gönüllülük hakkında bilgisi olan, ailesinde kendinden başka gönüllü olan, ortalama haftada yedi saat gönüllülük için zaman ayıran, günde yaklaşık iki saat TV izleyen ve TV'de Haber, Belgesel ve Kültür-Sanat programlarını izleyen, çok fazla 
kitap okumayan ve sinemaya gitmeyen bir profile sahiptirler.

Bireylerin AKUT’un Kentsel Operasyon Ekibi’nde gönüllü olma ve gönüllülüğü sürdürmelerinin gerekçeleri; "Bir Misyonu Onaylama", "Değerli Hissetme/Başarma", "Yenileme/ Yenilenme”, "Örnek Olma”, “Beceri Kullanma/İşe Yarama” ve "Gönüllülüğ̈̈ Yaşama”dır. Bu faktörlerin önemli bir kısmı birçok demografik değişkene göre farklılık göstermemektedir. Farklılık olan faktörlerden "Bir Misyonu Onaylama" da erkeklerin lehine, "Yenileme/Yenilenme" de Y1 yaş gurubu lehine, "Örnek Olma" da düşük gelir grubunun aleyhine, erkeklerin ve evlilerin lehine istatistiki olarak anlamlı fark vardır.

Bunun yanında bireyleri rekreatif etkinliklere katılmaya motive eden birçok faktörün bireylerin AKUT'un Kentsel Operasyon Ekibi'nde gönüllü olması için önem arz etmediği, bu kurumda olma gerekçeleri sıradan, gündelik bir serbest zaman faaliyeti olan gönüllülük yerine ciddi boş zaman faaliyeti olan gönüllülüktür.

\section{KAYNAKÇA}

Alkan T. (1989). Siyasal Bilinç ve Toplumsal Değişim. Ankara1989.

Allison L. D., Okun M. A. \& Dutridge K. S (2002). "Assessing Volunteer Motives: A Comparison of an Open-Ended Probe and Likert Rating Scales”. J. Community Appl. Soc. Psychol. 12 (2002) 243-255. Doi: $10.1002 /$ casp.677.

Ardahan F. (2010). “Gönüllü Olmak”. Kaynak: http://www.antalyabugun.com/?page=makale\&MID=109 31. Erişim Tarihi: 23/06/2015.

Ardahan F. (2011). "The Profile of The Turkish Mountaineers and Rock Climbers: The Reasons and The Carried Benefits for Attaending Outdoor Sports and Life Satisfaction Level”. 8. International Conference Sport and Quality of Life/2011, 10-11 November 2011, Congress Centre-Brno/Czech Republic.

Ardahan F. (2013). "Rekreasyonel Egzersize Güdüleme Ölçeği'nin Rekreatif Spor Türüne Göre İncelenmesi: Antalya Örneği”. Iğdır Üniversitesi Sosyal Bilimler Dergisi 4 (2013) 95-108.

Ardahan F. (2014). "Bireylerin Sosyal Sermaye Profili: Antalya Örneği”. ASOS Journal, Akademik Sosyal Araştırmalar Dergisi 2/8 (2014) 38-56. Doi: dx.doi.org/10.16992/ASOS.435

Ardahan F. (2015a). "Developing and Doing Validity and Reliability of the Motivational Factors Scale for being Volunteer in AKUT". International Conference on the Changing World and Social Research I, 25-28 August 2015, Vienna.

Ardahan F. (2015b). "Recreational Importance and Reasons for Being Preferred of Countryman Coffee Stall as Communal Place”. Social Sciences and Humanities in Focus. Sosyal ve Beșeri Bilimlere Küresel Yaklaşımlar Kuram ve Uygulamalar Uluslar Arası Sempozyum. Polonya Bilimler Akademisi Varşova, Polonya, 16-18 Eylül 2015, Bildiriler Kitabı.

Bang H. \& Ross S. D. (2009). "Volunteer Motivation and Satisfaction". Journal of Venue and Event Management 1/1 (2009) 61-77.

Bequette C. (1990). Volunteers on Volunteering: A Narrative Analysis of Interviews with Red Cross Disaster Volunteers. Unpublished Masters Thesis. Regent University, Virginia Beach, VA 1990.

Berger G. (1991). Factors Explaining Volunteering for Organizations in General and for Social Welfare Organizations in Particular. Unpublished Doctoral Dissertation. Heller School of Social Welfare, Brandais University, Waltham, MA 1991.

Black B. \& DiNitto D. (1994). "Volunteers who Work with Survivors of Rape and Battering: Motivations, Acceptance, Satisfaction, Length of Service, and Gender”. Journal of Social Service Research 20/1-2 (1994) 73-97.

Brown S. (2005). "Travelling with a Purpose: Understanding the Motives and Benefits of Volunteer Vacationers”. Current Issues in Tourism 8/6 (2005) 479-496. Doi: 10.1080/13683500508668232.

Burke D. M. \& Hall M. (1986). "Personality Characteristics of Volunteers in a Companion for Children 
Program”. Psychological Reports 59 (1986) 819-825.

Clary E. G. \& Snyder M. (1999). “The Motivations to Volunteer: Theoretical and Practical Considerations”. Current Directions in Psychological Science 8 (1999) 156-161. Doi: 10.1111/14678721.00037.

Clary E. G., Snyder M., Ridge R. D., Stukas A. A., Haugen J. \& Miene P. (1998). "Understanding and Assessing the Motivations of Volunteers: A Functional Approach”. Journal of Personality and Social Psychology 74/6 (1998) 1516-1530.

Farmer S. M. \& Fedor D. B. (2001). "Changing the Focus on Volunteering: an Investigation of Volunteers’ Multiple Contributions to a Charitable Organization”. Journal of Management 27 (2001) 191-211.

Farrell J. M., Johnston M. E. \& Twynam D. (1998). "Volunteer Motivation, Satisfaction and Management at an Elite Sporting Competition”. Journal of Sport Management 12 (1998) 288-300.

Finkelstien M. A. (2009). "Intrinsic vs. Extrinsic Motivational Orientations and the Volunteer Process”. Personality and Individual Differences 46 (2009) 653-658.

Fisher L. R. \& Schaffer K. B. (1993). Older Volunteers: A guide to Research and Practice. Sage, Newbury Park 1993.

Gallant K. A. (2010). Feelings of Obligation Related to Volunteering as Serious Leisure Within a Communitarian Framework. A Thesis Presented to the University of Waterloo in fulfillment of the Thesis Requirement for the Degree of Doctor of Philosophy in Recreation and Leisure Studies. Waterloo, Ontario, Canada 2010.

Gravelle F. \& Larocque L. (2005). "Volunteerism and Serious Leisure: The Case of the Francophone Games”. World Leisure Journal 47/1 (2005) 45-51. Doi:10.1080/04419057.2005.9674385.

Giannoulakis C., Wang C. H. \& Gray D. (2008). "Measuring Volunteer Motivation in Mega-Sporting Events”. Event Management 11 (2008) 191-200.

Henderson K. A. (1981). “Motivations and Perceptions of Volunteerism as a Leisure Activity”. Journal of Leisure Research 13/1 (1981) 208-218.

Henderson K. A. (1984). “Volunteerism as Leisure”. Journal of Voluntary Action Research 13 (1984) 55-63.

Ibrahim H. \& Cordes K. A. (2002²). Outdoor Recreation, Enrichment For a Lifetime. Urbana, IL 2002.

İ̆ci A. (2008). Sivil Toplum Kuruluşu Üyeliğinin Siyasal Katılma Davranışı Üzerindeki Etkisi: Isparta Örnek Olayı. Yayımlanmamış Yüksek Lisans Tezi. Süleyman Demirel Üniversitesi, Sosyal Bilimler Enstitüsü, Kamu Yönetimi Anabilim Dalı, Isparta 2008.

Kim M., Zhang J. J. \& Connaughton D. (2010) "Modification of the Volunteer Functions Inventory for Application in Youth Sports”. Sport Management Review 13 (2010) 25-38.

Knoke D. \& Prensky D. (1984). "What Relevance Do Organization Theories Have for Voluntary Associations?”. Social Science Quarterly 65/1 (1984) 3-20.

Lammers J. C. (1991). “Attitudes, Motives, and Demographic Predictors of Volunteer Commitment and Service Duration”. Journal of Social service Research 14/3-4 (1991) 125-140.

Mirsafian H. \& Mohamadinejad A. (2012). "Sport Volunteerism: a Study on Volunteering Motivations in University Students”. Journal Of Human Sport \& Exercise 7/PROC1 (2012) 73-84.

Mowen J. C. \& Sujan H. (2005). "Volunteer Behavior: A Hierarchical Model Approach for Investigating Its Trait and Functional Motive Antecedents”. Journal of Consumer Psychology 15/2 (2005) 170-1 82.

Özdemir S., Basel H. \& Şenocak H. (2009). “Sivil Toplum Kuruluşları (STK)'nın Artan Önemi ve Üsküdar'da Faaliyet Gösteren Bazı STK'lar Üzerine Bir Araştırma”. Sosyal Siyaset Konferansları Dergisi 56 (2009)151-234.

Perkins K. B. (1989). “Volunteer Firefighters in the United States: A Descriptive Study”. Nonprofit and Voluntary Sector Quarterly 18/3 (1989) 269-277.

Rohs F. R. (1986). "Social Background, Personality, and Attitudinal Factors Influencing the Decision to Volunteer and Level of Involvement Among Adult 4-H Leaders”. Journal of Voluntary Action Research 15/1 (1986) 87-99.

Stebbins R. A. (1992) Amateurs, Professionals, and Serious Leisure. Montreal, PQ and Kingston, ON 1992. 
Stebbins R. A. (1996a). The Barbershop Singer: Inside the Social World of a Musical Hobby. Toronto 1996. Stebbins R.A. (1996b). "Volunteering: A Serious Leisure Perspective". Nonprofit and Voluntary Sector Quarterly 25 (1996) 211-224.

Stebbins R. A. (1997). “Casual Leisure: a Conceptual Statement”. Leisure Studies 16 (1997) 17-25.

Stebbins R. A. (2004). "Serious Leisure, Volunteerism and Quality of Life”. Eds. John T. H. \& Veal A. J. Work and Leisure (2004) 200-212. New York.

Stebbins R. A. (2013). "Unpaid Work of Love: Defining the Work-Leisure Axis of Volunteering”. Leisure Studies 32/3 (2013) 339-345. Doi:10.1080/02614367.2012.667822.

Stebbins R. A. \& Parker S. R. (1994). "Work and Leisure: The Experience Dimension”. Paper presented at the annual meeting of Canadian Sociology and Anthropology Association, Calgary, Alberta.

STGM (2006). (=Sivil Toplum Geliştirme Merkezi). Stk'lar İçin Gönüllülük ve Gönüllü Yönetimi Rehberi. Ankara 2006.

Sundeen R. A. (1992). "Differences in Personal Goals and Attitudes Among Volunteers". Nonprofit and Voluntary Sector Quarterly 21 (1992) 271-291.

Terrell F., Mosley K. L Terrell A. S. \& Nickerson K. J. (2004). "The Relationship Between Motivation to Volunteer, Gender, Cultural Mistrust, and Willıngness to Donate Organs Among Blacks”. Journal of the National Medical Association 96/1 (2004) 53-60.

Thomson A. M. \& Bono B.A. (1993). "Work Without Wages: The Motivation of Volunteer Firefighters". American Journal of Economics and Sociology 52 (1993) 323-343. Doi: 10.1111/j.15367150.1993.tb02553.x

Twynam G. D., Farrell J. M. \& Johnston M. E. (2002). "Leisure and Volunteer Motivation at a Special Sporting Event”. Leisure/Loisir 27 (2002) 363-377. Doi:10.1080/14927713.2002.9651310.

Van Til J. (1988). Mapping the Third Sector: Voluntarism in a Changing Political Economy. New York 1988.

Wymer W., Riecken G. \& Yavas U. (1996). "Determinants of Volunteerism: A Cross-Disciplinary Review and Research Agenda". Journal of Nonprofit \& Public Sector Marketing 4/4 (1996) 3-26.

Yarnal C. M. \& Dowler L. (2002). "Who is Answering the Call? Volunteer Firefighting as Serious Leisure”. Leisure/Loisir 27 (2002) 3-4, 161-189. Doi: 10.1080/14927713.2002.9651302. 